\title{
The Influence of Academic Stress and Adversity Intelligence on School Well-Being
}

\author{
Diyah Fitriasti Khoirunnisa ${ }^{1 *}$, Nurul Hidayah ${ }^{2}$, Yuzarion $^{3}$ \\ ${ }^{1}$ Postgraduate Program, Faculty of Psychology, Ahmad Dahlan University, Yogyakarta 55166, \\ Special Region of Yogyakarta, Indonesia \\ ${ }^{2,3}$ Faculty of Psychology, Ahmad Dahlan University, Yogyakarta 55166, Special Region of \\ Yogyakarta, Indonesia
}

*) Corresponding author: diyahfitriastik@gmail.com

\begin{abstract}
Learning should provide a pleasant atmosphere for students to fulfill their curiosity. A comfortable atmosphere will bring up student welfare (school well-being). This study aims to determine the influence of academic stress and adversity intelligence on school well-being in Muhammadiyah Al Mujahidin Junior High School students while studying from home during the Covid-19 pandemic. The method researchers use in data collection is a quantitative approach and data collection with a scale or questionnaire and is carried out in June-October 2021. Respondents in this study are junior high school students aged 12-15 years. The number of respondents in this study was 253 students at SMP Muhammadiyah Al Mujahidin. Data collection in this study was conducted using Google Form. The sampling technique used in this research is cluster random sampling. The instrument used is the academic stress scale, adversity intelligence scale, and scale of school well-being. The data analysis technique used is multiple linear regression analysis. Results of addressing a major hypothesis there is a highly significant association of academic stress and adversity intelligence to the well-being of school students of SMP Muhammadiyah AlMujahideen while studying from home to the pandemic covid 19.
\end{abstract}

Keywords: academic stress, adversity intelligence, school well-being

\begin{abstract}
Abstrak
Pembelajaran harus mampu memberikan suasana yang menyenangkan bagi siswa untuk memenuhi rasa ingin tahunya. Suasana yang nyaman akan memunculkan kesejahteraan siswa di sekolah (school well-being). Penelitian ini bertujuan untuk mengetahui pengaruh stres akademik dan kecerdasan adversitas terhadap kesejahteraan sekolah pada siswa SMP Muhammadiyah Al Mujahidin saat belajar dari rumah selama masa pandemi Covid-19. Metode yang digunakan peneliti dalam pengumpulan data adalah pendekatan kuantitatif dan pengumpulan data dengan skala atau angket dan dilaksanakan pada bulan Juni-Oktober 2021. Responden dalam penelitian ini adalah siswa SMP berusia 12-15 tahun. Jumlah responden dalam penelitian ini adalah 253 siswa di SMP Muhammadiyah Al Mujahidin. Pengumpulan data dalam penelitian ini dilakukan dengan menggunakan Google Form. Teknik pengambilan sampel yang digunakan dalam penelitian ini adalah cluster random sampling. Instrumen yang digunakan adalah skala stres akademik, skala kecerdasan adversitas dan skala kesejahteraan sekolah. Teknik analisis data yang digunakan adalah analisis regresi linier berganda. Hasil menjawab hipotesis utama terdapat hubungan yang sangat signifikan antara stres akademik dan kecerdasan adversitas terhadap kesejahteraan siswa sekolah SMP Muhammadiyah Al Mujahidin selama belajar dari rumah dengan pandemi covid-19.
\end{abstract}

Kata kunci: kecerdasan adversitas, kesejahteraan sekolah, stress akademik 


\section{Introduction}

Education has an important role in developing the potential of human resources to become a quality generation so that it will be beneficial for the progress of the nation and state in the future. Education and the learning process are two things that cannot be separated. Therefore, the learning process in the classroom is expected to provide a comfortable learning atmosphere and encourage students' willingness to learn actively.

Learning should provide a pleasant atmosphere for students to fulfill their curiosity. A comfortable atmosphere will bring up student welfare (school well-being). School wellbeing is defined as the state of students who achieve a degree of satisfaction in meeting the needs of school conditions (having), social relationships (loving), self-fulfillment (being), and health status (Konu \& Rimpela, 2002). Therefore, the concept of school wellbeing can be used to get a picture of improving student welfare in schools. School wellbeing is complex because it involves various important elements in the learning and teaching process. Teachers and students as actors in the process and the environment outside, especially the school itself, parents of students, and all the facilities, will support the learning process to be more effective (Ramdani \& Prakoso, 2019).

Student welfare at school, also known as school well-being according to (Konu \& Rimpela, 2002), is defined as the state of students who achieve a degree of satisfaction in meeting the needs for school conditions (having), social relationships (loving), selffulfillment (being), and health status (health). Therefore, the concept of school well-being can be used to improve student welfare in schools. The main goal is to fulfill the welfare of students and fulfill the achievements, potentials, and physical and mental abilities of students (Konu, Alanen, Lintonen, \& Rimpela, 2002). The results of Setiyawan and Dewi (2015) revealed that school well-being could be useful in helping to create a conducive learning environment so that learning objectives can be achieved. In addition, positive support for students who come from a friendly environment and teachers can positively impact business and encourage achievement (Bakadorova, 2014).

Based on the interviews with Guidance and Counseling teachers at SMP Muhammadiyah Al Mujahidin, it shows that learning during the Covid-19 pandemic is carried out online or online with learning from home with guidance from teachers and parents. This is in accordance with circular letter number 421/2210/MP-1, which issued a policy for students at PAUD, TK/RA, SD/MI, SMP/MTS, and SMA/MA levels in Gunungkidul Regency to carry out learning from home (LFH) regularly. Distance/online learning for students and teachers to work from home (WFH) (Diksdipora, 2020).

Based on the above, the researchers conducted a preliminary survey by giving class VIII and IX students an open questionnaire on July 21, 2021, showing that during the pandemic, students felt the difference when they could not learn directly face to face. The survey results also show that students experience a fairly dense learning schedule and many tasks given by the teacher so that they are confused in managing working time. Adaptation to the distance learning curriculum online using Google Classroom, Quizzes, WhatsApp, and other media. Students feel that communication with the teacher is tenuous because they cannot meet face-to-face. Group dynamics or discussion forums are carried out with limited WhatsApp group media. Students feel that their relationship with classmates is limited because it is only through WhatsApp conversations.

According to the next survey results, the achievement of the one student one trophy student has decreased due to many non-school institutions that limit competition activities, both academic and non-academic, so that the target of 60 achievements each 
year decreases 30 achievements obtained. Students' self-fulfillment activities such as extracurricular activities, outdoor activities, camping, hiking, and others were discontinued during the pandemic. The health status of teachers and students experienced during the pandemic was that some were exposed to Covid-19, so they had to self-isolate. Students complain of headaches and indigestion when piling up assignments. The state of students who experience boredom, boredom, restlessness so that they experience stress piling up tasks and confused about setting a study schedule.

The survey results conducted by researchers to students as described above indicate low school well-being in students. Based on this, researchers are interested in knowing what predictors of behavior school well-being can be. Based on the results of previous research, one of the factors that influence school well-being is academic stress (Rabbani \& Sofia, 2019). According to Moore and Keyes (2003), factors that influence well-being are social relationships, friends and free time, volunteering, social roles, characteristics, goals, and aspirations.

The stress experienced by students plays an important role in the academic process. Stress can affect students physically and psychologically. The impact of stress experienced by students can be in the form of anxiety, nervousness, endless worries, and digestive disorders (Agolla, 2009). Academic stress is stress on students that comes from the teaching and learning process or things related to learning activities including pressure to go to class, length of study, many assignments, test scores, bureaucracy, getting scholarships, decisions to determine majors and careers as exam anxiety, and time management (Desmita, 2010).

Student assessments of schools affect students' well-being in schools (Evans, Martin, \& Pringle, 2018). According to Konu \& Rimpela (2002), students' assessment of school influenced by comfortable school conditions, good social relations, and student self-fulfillment impact high academic performance and good student health conditions. In addition, research (Faizah, Prinanda, Rahma, \& Dara, 2018) shows that students who can adapt to academic demands and feel comfortable studying at school tend to feel the existence of school well-being.

According to research by Rabbani \& Sofia (2019), there is a negative relationship between academic stress and school well-being, where the higher the academic stress, the lower the school well-being, and vice versa, the lower the academic stress, the higher the school well-being. Academic demands in schools negatively impact students, such as academic stress, reducing academic achievement, reducing learning motivation, and reducing student welfare in learning (Setiyawan and Dewi, 2015). The impact of stress experienced by students can be in the form of anxiety, nervousness, endless worries, and digestive disorders (Bakadorova, 2014).

Other studies mention the causes of academic stress can also be sourced from interactions between teachers and students, anxiety related to learning outcomes obtained, exams or tests to be faced, learning processes in groups, peer influence in the academic process, ability to manage time, and individual perceptions related to learning abilities that affect the academic performance displayed (Lue, Chen, Wang, Cheng, \& Chen, 2010).

According to research by Andriany and Setyawan (2016), there is a significant positive relationship between adversity intelligence and school well-being in students. The higher the level of adversity intelligence, the higher the school well-being of students, and conversely, the lower the adversity intelligence, the lower the school well-being of students. For some people, having an adversity intelligence low can lead to despair, giving 
up, and not wanting to try again. Still, failure is just an unfavorable result for some other people who have high adversity intelligence and can be repaired. Therefore, adversity intelligence is considered a factor is determining a person's attitude and ability to face difficulties (Stoltz, 2000).

The explanation above shows that the low level of students having adversity intelligence can cause despair, give up and do not want to try again, and impact the emergence of academic stress. Likewise, feeling uncomfortable and not feeling the welfare of school (school well-being) impacts high academic stress. Moreover, students' experiences about learning conditions in the classroom and student welfare conditions also impact academic performance. So, research on the determinants of academic stress becomes very important to do. Therefore, this study examines the influence of academic stress and adversity intelligence on school well-being.

\section{Participant}

\section{Methods}

This study used a quantitative research design. The research was conducted using a questionnaire. This research was conducted in June-October 2021. The sampling technique used in this study was random cluster sampling. Cluster sampling is done by randomizing the group, not the individual subject. Respondents in this study were junior high school teenagers in grades VIII and IX at SMP Muhammadiyah Al Mujahidin. The number of respondents in the study was 253 respondents.

\section{Measurement}

This study used three research variables: academic stress, adversity intelligence, and school well-being. School well-being is a student's assessment of the state of the school that can make students achieve satisfaction in meeting their basic needs at school as measured by aspects of school conditions (having), social relationships (loving), selffulfillment needs (being), and health status (health status). School well-being will be measured using the school well-being scale. The higher the score obtained, the higher the school's well-being level. On the contrary, the lower the score obtained, the lower the school well-being level.

Academic stress is psychological pressure caused by academic stressors with many demands in learning, the number of assignments given, anxiety about assessment, self-expectations, and uncertainty in facing academic obstacles based on aspects of academic stress, namely Self-expectation, Pressure from study, Workload, Worry about grade, Despondency. Academic stress will be measured using an academic stress scale. The higher the score obtained, the higher the level of academic stress. On the contrary, the lower the score obtained, the lower the level of academic stress.

Adversity Intelligence is the intelligence or ability of a person to make decisions in acting to survive and try to overcome difficulties. They will encourage him to try to achieve success in the future based on aspects of Control (C) or control, Origin, and Ownership (O2). Reach (R) or range, and Endurance (E) or endurance. Adversity Intelligence will be measured using the Adversity Intelligence scale. The higher the score obtained, the higher the Adversity Intelligence, the lower the score, the lower the Adversity Intelligence level.

The scale distribution using the google from link. The answer scale used a Likert scale with four alternative answers very inappropriate, not appropriate, appropriate, and 
very appropriate. Conduct trials on all three scales to obtain valid and reliable items. The scale in this study consisted of 35 items for the academic stress scale, 36 items for the adversity intelligence scale and 36 items for the school well-being scale. The researcher begins by providing instructions on how to fill out the scale so that the subject can fill in the answers according to the actual situation. Next, the subject was asked to fill in the scale that had been distributed. If all the scales have been filled in, the subject is asked to return the scale directly to the researcher for scoring and analysis purposes.

\section{Analysis}

Descriptive analysis aims to provide an overview of the research subject's response to the research variables. The scores displayed in the descriptive analysis table are basic statistical functions that include the minimum value, maximum value, mean, and standard deviation of two conditions, namely a hypothetical state (a condition that is predicted to occur) and an empirical state (a condition obtained by research data). After the data was collected, the researcher scored and analyzed the data with the help of the SPSS 26.0 for Windows computer program.

Determination of basic statistical values on hypothetical data is based on a research scale where the range of alternative answers on the academic stress scale, adversity intelligence, and school well-being moves from low to high, namely $1-5$. The following is the calculation of the intended hypothetical score. The school well-being scale consists of 14 items, allowing the lowest score (xr) of the data hypothetically to be the lowest score $(\mathrm{Xmin}) 1 \times 14=14$ and the highest score (Xmax) 5x14=70.

The calculation formula on the school well-being scale is also applied to the next two scales, namely the academic stress scale with 23 items and the Adversity Intelligence scale with 18 items. The data analysis method used in this study is multiple linear regression using SPSS. Before the analysis with regression, the analysis requirements test was carried out first. Test requirements analysis includes;

\section{Assumption}

\section{Test Normality Test}

The test aims to test whether the confounding variable or residue has a normal distribution in the regression model. The normality test in this study used the technique Kolmogorov-Smirnov (KS-Z) from the SPSS 26.0 for Windows program. The test criteria used are if $>0.05$, then the data distribution is normal, whereas if $<0.05$, the data distribution is not normal. A good regression model is a normal distribution or close to normal (Ghozali, 2018). Based on the normality test results, which show that the unstandardized residuals are the three academic stress variables, adversity intelligence school well-being, with a value of $\mathrm{p}=0.200$ ( $\mathrm{p}>0.05$ ), the data can be concluded is normally distributed. The normality test results for the distribution of each variable are presented below.

Table 1 . The results of the Normality Test

\begin{tabular}{cccc}
\hline Variable & $\begin{array}{c}\text { Kolmogorov- } \\
\text { Smirnov }\end{array}$ & Sig (p) & Information \\
\hline $\begin{array}{c}\text { Unstandardized } \\
\text { Residual }\end{array}$ & 0.46 & 0.200 & Normal \\
\hline
\end{tabular}




\section{The Linearity Test}

A linearity test is a regression line test between the independent variable and the dependent variable. The linearity test was carried out to see whether the specifications of the model used were correct or not and to ensure that the distribution of the values of the variables in this study could be drawn a straight line (linear) indicating a linear relationship between the research variables so that the independent and dependent variables could be correlated. There are two rules in the linearity test. First, if $p$ linearity $<0.05$, then the relationship is declared linear and if $\mathrm{p}$ linearity $>0.05$, the relationship is declared non-linear. Second, if $\mathrm{p}$ deviation from linearity $>0.05$, then the relationship is declared linear, and if $\mathrm{p}$ deviation from linearity $<0.05$, then the relationship is declared non-linear (Ghozali, 2018). Linearity test results can be seen in the table below.

Table 2. Test results

\begin{tabular}{lrrr}
\hline \multirow{2}{*}{ Variable } & \multicolumn{2}{c}{ Linearity } & Description \\
\cline { 2 - 3 } & \multicolumn{1}{c}{ F } & Sig $(\mathrm{p})$ & Linear \\
Academic stress with school well-being & 186.220 & 0.000 & Linear \\
Adversity intelligence with school well-being & 19.571 & 0.000 & \\
\hline
\end{tabular}

The results of the linearity test between school well-being and academic stress showed a significance level of $p$ (linearity) of $0.000(\mathrm{p}<0.05)$ which means that the two variables have a linear correlation. At the same time, the variable school well-being with adversity intelligence shows a significance level value of $p$ (linearity) of 0.000 ( $p<0.05$ ), which means that the two variables have a linear correlation.

\section{Multicollinearity}

The multicollinearity test was conducted to test whether the regression model found a correlation between the independent variables and the dependent variable. This test is carried out to clean the data from the possibility of two or more independent variables originating from the same concept. Testing for the presence or absence of multicollinearity symptoms can be done by looking at the VIF values (Variance Inflation Factor) and Tolerance. For example, if the VIF value is $<10$ and the Tolerance value is $>0.10$, it can be concluded that the regression model does not occur multicollinearity (Ghozali, 2018). The results of the multicollinearity test can be seen in the table below (Table 3).

Table 3. Test results multicollinearity

\begin{tabular}{lccr}
\hline Variable & Tolerance & VIF & Description \\
\hline academic stress & 0.863 & 1.159 & does not occur multicollinearity \\
Adversity & 0.863 & 1159 & does not happen multicollinearity \\
Intelligence & & & \\
\hline
\end{tabular}

The test results indicate that the value multicollinearity tolerance for variable commitment academic stress and adversity intelligence was $0.863(>0.10)$ and VIF variables school of well-being with academic stress and variable well-being of school with adversity intelligence of VIF $=1.159$. This means that all variables are declared not to have multicollinearity with VIF $<10$ criteria. Based on the results of the analysis of the multicollinearity test, it was found that there was no multicollinearity between the independent variables in the regression model so that it met the requirements for a regression analysis test. 


\section{Findings}

\section{Descriptive Analysis of Academic Stress, Adversity Intelligence, and Scholl Well- Being}

The data presented in this study provide a general description of the data obtained in the field. The description of the research variables can be seen from the hypothetical mean and empirical means and descriptions based on the normal distribution model. Any empirical mean score that is significantly higher than the hypothetical mean score can be considered an indicator of the high state of the subject group in the variables studied. On the other hand, any empirical score that is significantly lower than the hypothetical mean score can be considered an indicator of the low state of the subject group in the variables studied. The results of comparing the empirical mean and the hypothetical mean of each variable can be seen below (Table 4).

Table 4. Results of descriptive statistics calculation

\begin{tabular}{lrrrr}
\hline Variable & Min & Max & Mean & SD \\
\hline Academic stress & 23 & 115 & 69 & 15.3 \\
Adversity intelligence & 18 & 90 & 54 & 12 \\
School well-being & 14 & 70 & 42 & 8.5 \\
\hline
\end{tabular}

Table 5 above is then used to categorize the three research variables. The purpose of categorization is to determine the high and low scores obtained by the subject on each variable. Although the score will be classified using three categories, namely: high, medium, and low, to determine the categorization of each subject, you can use the categorization norm listed in the table below (Table 5).

Table 5. Categorization

\begin{tabular}{lr}
\hline Norm & Categorization \\
\hline $\mathrm{X}(\mathrm{M}+1.0 \mathrm{SD})$ & High \\
$(\mathrm{M}-1.0 \mathrm{SD}) \mathrm{X}(\mathrm{M}+1.0 \mathrm{SD})$ & Medium \\
$\mathrm{X}<(\mathrm{M}-1.0 \mathrm{SD})$ & Low \\
\hline
\end{tabular}

Based on the results of the categorization of academic stress scores, it shows that as many as $65(26 \%)$ students are in the category high, as many as $157(62 \%)$ students in the medium category, and as many as $31(12 \%)$ adolescents in the low category. The norm categorization concludes that the average research subject has a moderate academic stress behavior. The categorization of academic stress scores can be seen in Table 6 .

Results of categorization scores adversity intelligence show that as many as 127 $(50 \%)$ students are in the high category, as many as $123(49 \%)$ students are in the medium category. As many as $3(1 \%)$ adolescents are in a low category. The conclusion from the categorization of norms is that the average research subject has a relatively high behavior diversity intelligence. The categorization results of a score diversity intelligence can be seen in the table below (Table 6).

The results of the categorization of scores school well-being show that as many as $51(20 \%)$ students are in the high category, and as many as $134(53 \%)$ students in the medium category, and as many as $68(27 \%)$ students in the low category. The norm categorization concludes that, on average, the research subjects have behavior school well-being relatively moderate. The results of score categorization of school well-being can be seen in the table below (Table 6). 
Table 6. Categorization of adversity intelligence data

\begin{tabular}{lrrrr}
\hline Variable & Interval & Frequency & $\begin{array}{r}\text { Percentage } \\
(\%)\end{array}$ & Categorization \\
\hline Academic & X 84.3 & 65 & 26 & High \\
Stress & 53.7 X 84.3 & 157 & 62 & Medium \\
& X $<53.7$ & 31 & 12 & Low \\
\hline \multirow{2}{*}{ Adversity } & X 66 & 127 & 50 & High \\
Intelligence & 42 X 66 & 123 & 49 & Medium \\
& X $<42$ & 3 & 1 & Low \\
\hline School well- & X 50.5 & 51 & 20 & High \\
being & 33.5 X 50,5 & 134 & 53 & Medium \\
& X $<33.5$ & 68 & 27 & Low \\
\hline
\end{tabular}

\section{The Influence of Academic Stress and Adversity Intelligence on Scholl Well-Being}

Based on the results of multiple regression analysis for the major hypothesis, the score $\mathrm{R}=0.629$ with a significant level of $0.000(\mathrm{p}<0.01)$ so that the major hypothesis can be accepted. This shows a significant relationship between academic stress and adversity intelligence on school well-being with an effective contribution (R Square) of 0.395 , which means that academic stress and adversity intelligence simultaneously contribute 39.5 percent to school well-being. These results, it can be said that the first hypothesis proposed by the researcher is accepted. The multiple linear regression analysis results for the major hypothesis can be seen below (Table 9).

Table 7. Results of multiple linear regression

\begin{tabular}{lrrrrrr}
\hline Variable & R & R Square & F & Sig (p) & Description \\
\hline $\begin{array}{l}\text { Academic stress; adversity intelligence; } \\
\text { school well-being. }\end{array}$ & 0.629 & 0.395 & 81.630 & 0.000 & Very Significant \\
\hline
\end{tabular}

Data obtained from the results of data analysis known that the influence between academic stress variables to school well-being obtained a score of $r=0.628$ with $p=$ 0.000 ( $\mathrm{p}<0.001)$ so that the first minor hypothesis is accepted. This shows a significant relationship between the academic stress variable and school well-being, which means that the lower the academic stress, the higher the school's well-being. On the other hand, the higher the academic stress, the lower the school's well-being (Table 8).

The findings in the field that students have a fairly high school well-being are caused because students can manage stress during the COVID-19 pandemic, such as having adequate facilities to feel comfortable while studying. The existence of relatively low academic stress is due to students coping with stress by doing useful activities such as tutoring (bimbel), asking the teacher when experiencing difficulties, being active during learning, and so on.

The results of the analysis that the magnitude of the influence between the variable adversity intelligence and school well-being obtained a coefficient of $r=0.253$ with a value of $p=0.007(p<0.05)$ so that it shows that there is a positive relationship between the variable adversity intelligence and school well-being, which means the lower adversity intelligence, the lower the school well-being. On the other hand, the higher the adversity intelligence, the higher the school's well-being.

The findings in the field show that students have quite high adversity intelligence. Students have a fairly good ability to overcome difficulties. They have the ability but are less empowered, especially in big changes that require them to adapt, so they stop trying when the difficulty starts to feel threatening. Very high category amounted to 127 people 
$(50 \%)$. This category is a group of subjects who take existing difficulties as opportunities to continue to develop their potential. Each has as much as one person in the low and very low categories $(1 \%)$. This category indicates subjects who have inadequate abilities in dealing with difficulties and avoiding responsibility, easily despair, and stop trying when faced with difficulties.

Table 8. Minor hypothesis test results

\begin{tabular}{lrrr}
\hline Variable Zero Order (r) & Sig $(\mathrm{p})$ & Description \\
\hline $\begin{array}{l}\text { Academic stress; } \\
\text { adversity intelligence; }\end{array}$ & 0.628 & 0.000 & Very Significant \\
$\begin{array}{l}\text { school well-being } \\
\text { Academic stress; }\end{array}$ & & & \\
adversity intelligence; & 0.253 & 0.007 & significant \\
school well-being & & & \\
\hline
\end{tabular}

\section{Discussion}

The major hypothesis shows a relationship between academic stress and adversity intelligence with school well-being. The analysis results show that this study's hypothesis is accepted, which explains that there is a very significant relationship between academic stress and adversity intelligence with school well-being. In addition, Soutter (2012) states that school well-being as a multidimensional concept is a complex phenomenon involving seven interdependent domains, namely having, being, relating, thinking, feeling, functioning, and striving, organized into three categories: assets appraisals and action. Khatimah (2015) defines school well-being as the student's assessment of their school and its role in the student's learning process. The school well-being model above is shown from the student's point of view, which consists of four aspects, namely having (school conditions), loving (social relationships), being (self-fulfillment), and health (status).

This is following previous research conducted by Rabbani \& Sofia (2019) that there is a significant relationship between academic stress and school well-being to accept the hypothesis. This research hypothesizes that there is a negative relationship between academic stress and school well-being, where the higher the academic stress, the lower the school well-being, and vice versa, the lower the academic stress, the higher the school well-being.

The research of Faizah et al. (2018) shows that students who can adapt to academic demands and feel comfortable studying at school tend to feel the existence of school wellbeing. Students who feel high school well-being tend to have low academic stress. On the other hand, students who have low school well-being tend to have a greater chance of experiencing academic stress. According to Stecker (2004), students who feel well-being in their academic environment will avoid depression and stress. Students' experiences of feeling comfortable in school impact feelings of student's well-being and affect academic performance (Murray-Harvey, 2010). Thus, school well-being can be used to predict academic stress tendencies.

The norm categorization is that the average research subject's behaviour school well-being is relatively moderate. The findings of this study indicate the tendency of students to have moderate school well-being. The findings of this study support the findings of previous studies such as Muchsini and Siswandari (2020), which states that an unfavourable classroom culture affects academic stress. Students who perceive the 
classroom atmosphere negatively tend to experience stress. Meanwhile, according to Chemers (2001), student adjustment and classroom problems also affect students' academic stress. Unpleasant, stressful, and boring school conditions result in students' mindsets that negatively impact stress, boredom, isolation, loneliness, and depression (Azmy, Nurihsan, \& Yudha, 2017). According to (Wiks 2008; Agnitori, 2010), academic stress is mental stress resulting from a combination of academic demands that exceed an individual's ability to adapt and anticipated frustration associated with academic failure or even awareness of the failure.

The second minor hypothesis examines whether there is a relationship between adversity intelligence and school well-being for SMP Muhammadiyah Al Mujahidin students while learning from home (LFH) during the covid 19 pandemic. Adversity intelligence and school well-being have a significant relationship. Adversity intelligence is the ability to think, manage, and direct actions that form patterns of cognitive and behavioral responses to stimulus events in life that are challenges and or difficulties (Yazid, 2005). According to Rohman and Fauziah (2016), the results show a significant positive relationship between adversity intelligence and school well-being for SMA Kesatrian 1 Semarang students. The higher the adversity intelligence of students, the higher the school well-being they have, and vice versa.

The frequency distribution of hypothetical data results that categorize scores adversity intelligence shows that as many as $127(50 \%)$ students are in the high category. As many as 123 (49\%) students are in the medium category, and as many as $3(1 \%)$ adolescents are in a low category. The categorization of norms concludes that the average research subject's behavior and adversity intelligence are relatively high. The categorization of norms concludes that the average research subject's behavior and adversity intelligence are relatively high.

Another factor that may have an effect is related to the characteristics of the research subjects. The subjects of this study carried out learning, namely learning from home (LFH) online, so the fighting spirit in the spirit of learning tends to decrease. Stoltz (2007), in his research, found that the helplessness experienced by these individuals had negative impacts, including reduced performance, productivity, motivation, energy, willingness to learn, self-improvement, courage to take risks, creativity, vitality, tenacity, and perseverance. This helplessness makes individuals become campers (those who camp) and quitters (those who quit) - another influence from the closest people. According to Stoltz (2009), his research shows that responses to difficulties are formed through parents, teachers, and friends. Relationships with teachers and friends are tenuous and less communicative, thereby reducing adversity intelligence in students.

Based on the explanation above, it can be concluded that school well-being in students is more influenced by internal factors, namely high academic stress. At the same time, adversity intelligence has less impact and influence on achieving student school well-being. This study also found a weakness, namely that the sample could not be taken representatively because the position of the students was at home and taken online. Hence, the explanation was less than optimal. It could not be observed directly when students filled out the scale. The number of items on the research scale is large, so students are less enthusiastic in the filling process at the time of data collection in the field. 


\section{Conclusion and Recommendations}

\section{Conclusion}

Based on the research and discussion results, the categorization of academic stress shows that one-third of students are in the medium category. Half of the students are in the high category of adversity intelligence and medium category of school well-being. There is a significant influence of academic stress and adversity intelligence on school well-being. The results mean that the lower the academic stress, the higher the school's well-being. On the other hand, the higher the academic stress, the lower the school's wellbeing. There is a significant influence of adversity intelligence on school well-being for grade VIII and IX students SMP Muhammadiyah Al Mujahidin while Learning From Home (LFH) during the covid-19 pandemic. The higher the adversity intelligence of students, the higher the school well-being they have, and vice versa.

\section{Recommendation}

Based on the results obtained from the research, the researcher provides suggestions that can improve school well-being in schools. Junior high school students who have low school well-being should be able to increase adversity intelligence by being more diligent in studying, actively participating in school activities, reading more books related to selfdevelopment, and increasing motivation in learning such as Andrea Herata's novels, Biographies of characters and heroes and so on increasing a sense of responsibility to expand control, empowerment, and motivation to take action. For schools, it is necessary to continue to strive to improve school well-being by designing programs that can increase students' adversity intelligence and cultivate the mentality of seeing opportunities in every obstacle. These programs can be in the form of extracurricular activities that educate mentally not to give up, creating a positive learning climate by always providing positive feedback on student performance so that students' self-esteem and sense of support grow, for further researchers interested in conducting research using the school well-being variable to be more specific and deeper about these variables. Future researchers are expected to be able to develop wider and varied items. Further researchers can also take subjects from other new schools to obtain new results and add references in research with other methods so that the generalization of the research is broader and obtains representative results regarding school well-being.

\section{References}

Agnitori, A. (2010). Stres and Student. Hiils borought ST: Lulu Publication.

Agolla, J. E. (2009). An assessment of academic stress among undergraduate students. The case of University of Botswana.

Andriyani, N.F., \& Setyawan, I. (2016). Adversity intelligence dan kesejahteraan sekolah pada siswa kelas XI dan XII. Jurnal Empati, 5(1), 24-27.

Ang, R. P. (2006). Relationship between academic stress and suicidal ideation: Testing for depression as a mediator using multiple regression. Child Psychiatry Hum Dev, 37, 133-143. Doi: 10.1007/s10578-006-0023-8

Azmy, A.N., Nurihsan, A.J., \& Yudha, E.S. (2017). Deskripsi gejala stres akademik dan kecenderungan pilihan strategi coping siswa berbakat. Indonesian Journal of 
Educational Counseling, 1(2), 197-208. Doi: https://doi.org/10.30653/001.201712.14

Azwar, S. (2012). Relibilitas dan validitas. Yogyakarta(ID): Pustaka Belajar.

Bakadorova. (2015). The mediating role of socio-motivational support in the association between individual school self-concept and achievement motivation amongst adolescent students. European Journal of Psychology of Education, 29(3), 347-366. Doi: https://doi.org/10.1007/s10212-013-0202-5

Bedewy, D. \& Gabriel, A. (2015). Examining perceptions of academic stress and its sources among university students: The perception of academic stress scale. Health Psychology Open, 2(2), 1-9. Doi: 10.1177/2055102915596714

Chemers, M. M. (2001). Academic self-efficacy and first year college student performance and adjustment. Journal of Educational Psychology, 93(1), 55-64. Doi: 10.1037//0022-0663.93.1.55

Danim, S. (2010). Perkembangan Peserta Didik. Bandung(ID): Alfabeta.

Dara, Y. P. (2018). School well-being pada siswa berprestasi sekolah dasar yang melaksanakan program penguatan pendidikan karakter. Psympathic: Jurnal Ilmiah Psikologi, 5(2), 161-174. Doi: 10.15575/psy.v5i2.3313

Desmita, (2010). Psikologi perkembangan peserta didik. Bandung(ID): Remaja Rosdakarya.

Diksdipora. (2020). Surat Edaran Kebijakan Belajar Dari Rumah (BDR). Gunungkidul(ID): Surat edaran nomor 421/2210/MP-1.

Evans, P., Martin, A.J., \& Pringle, Z.I. (2018). Personality, coping, and school wellbeing: an investigation of high school students. Social Psychology of Education, 21(5), 1061-1080. Doi: 10.1007/s11218-018-9456-8

Faizah, F., Prinanda, J.N., Rahma, U, \& Dara, Y.P. (2018). School well-being pada siswa berprestasi sekolah dasar yang melaksanakan program penguatan pendidikan karakter. Psympathic: Jurnal Ilmiah Psikologi, 5(2), 161-174..

Ghozali, I. (2018). Aplikasi analisis multivariate dengan program IBM SPSS 25. Semarang(ID): Badan Penerbit Universitas Diponegoro.

Huebner, S.E., \& McCullough, G. (2000). Correlates of school satisfaction among adolescents. The Journal of Educational Research, 93(5), 331-335 Doi: $10.1080 / 00220670009598725$

Khatimah, H. (2015). The description of school well-being in students of the accelerated class program at SMA Negeri 8 Yogyakarta. Journal of Psychopedagogia, 4(1), 2030.

Konu, A., \& Rimpela, M. (2002). Well-being in school: A conceptual model. Health Education Research, 17(1), 79-87. Doi: 10.1093/heapro/17.1.79.

Konu, A., Alanen, E., Lintonen, T., \& Rimpela, M (2002). Factor structure of the school well-being model. Health Education Research, 17(6), 732-742. Doi: https://doi.org/10.1093/her/17.6.732

Lue, B.H., Chen, H.J., Wang, C.W., Cheng, Y., \& Chen, M.C. (2010). Stress, personal characteristic and burnout among first postgraduate year residents: a nation wide study in Taiwan. Medical Teacher, 32(5), 400-407. Doi: $10.3109 / 01421590903437188$

Moore \& Keyes, C. L. (2003). Dimension of well-being and mental health in adulthood. In Bornstein, M. H. et al. (Eds), Well-being (Positive development across the life course), 487-491. United Kingdom: Taylor \& Francis e-Library. 
Muchsini, B., \& Siswandari, S. (2020). Class Culture And The Academic Stress Of Digital Natives Generations. Jurnal Cakrawala Pendidikan, 39(1), 102-110. Doi: 10.21831/cp.v39i1.26910

Murray-Harvey, R. (2010). Relationship influences on students' academic achievement, psychological health and well-being at school. Educational and Child Psychology, 27(1), 104-115.

Nurihsan, Y. A. (2017). Deskripsi gejala stres akademik dan kecenderungan pilihan strategi coping siswa berbakat. Indonesian Journal of Educational Counseling, 1(2), 197-208. Doi: 10.30653/001.201712.14

Rabbani, M.D., \& Sofia, N. (2019). Hubungan antara stres akademik dan school wellbeing pada siswa SMA di Yogyakarta. Yogyakarta(ID), Universitas Islam Indonesia.

Ramdani, Z., \& Prakoso, B.H. (2019). Integritas akademik:prediktor kesejahteraan siswa di sekolah. Indonesian Journal of Educational Assessment, 2(1), 30. E-ISSN: 26848074.

Rohman, I.H., \& Fauziah, N. (2016). Hubungan antara adversity intelligence dengan school well-being studi pada siswa SMA Kesatrian 1 Semarang. Jurnal Empati, 5(2), 322-326.

Rubie-Davies, C. (2014). Becoming A High Expectation Teacher: Raising The Bar. Auckland(NZ): Routledge

Setiyawan, I., \& Dewi, K.S. (2015). Kesejahteraan sekolah ditinjau dari orientasi belajar mencari makna dan kemampuan empati siswa sekolah menengah atas. Jurnal Psikologi Undip, 14(1), 9-20.

Stecker, T. (2004). Well-being in an academic environment. Medical Education, 8(5), 465-478. Doi: 10.1046/j.1365-2929.2004.01812.x

Stoltz, P. (2000). Adversity quotient at work: Mengatasi kesulitan di tempat kerja, mengubah tantangan sehari-hari menjadi kunci sukses anda. Jakarta(ID): Interaksara.

Stoltz, P. (2000). Adversity quotient, Mengubah hambatan menjadi peluang. Jakarta(ID): PT Gramedia Widiasarana Indonesia.

Stoltz, P. (2007). Adversity Quotient: Mengubah Hambatan Menjadi Peluang (terjemahan). Jakarta(ID): Grasindo.

Stoltz, P. (2009). Adversity Quotient: Mengubah Hambatan Menjadi Peluang (terjemahan). Jakarta(ID): Grasindo.

Sudiana, D. (2007). Kondisi stres siswa SMK dan faktor-faktor penyebabnya. Bandung: Skripsi Universitas Pendidikan Indonesia.

Sun, J. Dunne, J., \& Hou, M.P. (2011). Educational stress scale for adolescents: Development, validity and reliability with chinese students. Journal of Psychoeducational Assessment, 29 (6), 534-546. Doi: 10.1177/0734282910394976

Wiks, S. (2008). Resillience and academic stress: the moderatibg impact of social support among social work student. 9(2), 106-125.

Yazid, F. (2005). Hubungan antara Motivasi Berprestasi dengan Adversity Intelligence di Bidang Musik pada Personel Band di Yogyakarta. Skripsi (tidak diterbitkan). Yogyakarta: Fakultas Psikologi Universitas Gajah. 